\title{
Peran Tokoh Perempuan dalam Mengatasi Keemiskinan pada Novel Genduk Karya Sundari Mardjuki
}

\author{
Bagus Afiansah $^{\bowtie}$, Sumartini, Maharani Intan Andalas IRP \\ Jurusan Bahasa dan Sastra Indonesia, Fakultas Bahasa dan Seni, Universitas Negeri Semarang, \\ Indonesia
}

\begin{tabular}{l}
\hline Info Artikel \\
\hline Sejarah Artikel: \\
Diterima April 2018 \\
Disetujui Mei 2018 \\
Dipublikasikan Juli 2018 \\
\hline Keywords: \\
Womens' role; proverty; \\
gender construction; \\
literature feminism critique.
\end{tabular}

\begin{abstract}
Abstrak
Penelitian ini dilandasi oleh kondisi kaum perempuan yang rentan mengalami kemiskinan. Banyak karya sastra yang digunakan sebagai kritik sosial terhadap permasalahan yang ada dalam kehidupan nyata, salah satunya adalah novel Genduk karya Sundari Mardjuki. Penelitian ini bertujuan untuk : mendeskripsikan gambaran kemiskinan yang dialami tokoh perempuan, mendeskripsikan konstruksi gender, dan mendeskripsikan peran-peran tokoh perempuan mengatasi kemiskinan dalam novel Genduk karya Sundari Mardjuki.

Sumber data penelitian ini adalah novel Genduk karya Sundari Mardjuki yang diterbitkan oleh Gramedia Pustaka Utama pada tahun 2016. Metode penelitian yang digunakan adalah deskriptifkualitatif dengan pendekatan kritik sastra feminis. Penelitian ini difokuskan pada kemiskinan yang dialami tokoh perempuan dan peran mereka mengatasi kemiskinan tersebut. Data diperoleh dengan menggunakan teknik baca-catat.

Hasil analisis dari penelitian ini adalah sebagai berikut. 1) Terdapat gambaran kemiskinan yang dialami tokoh perempuan Genduk dan Yung yaitu tidak terpenuhinya kebutuhan dasar dengan layak. Kemiskinan yang dialami Genduk dan Yung disebabkan oleh ketergantungan pada satu sumber penghasilan sebagai petani tembakau dan konstruksi gender. Kemiskinan yang dialami Genduk dan Yung mengakibatkan ketergantungan pada pihak lain. 2) Kontruksi gender terdapat pada semua tokoh baik laki-laki maupun perempuan, tetapi tidak semua tokoh memiliki konstruksi gender yang dilekatkan masyarakat. Tokoh perempuan seperti Genduk, Bu As, dan Yung adalah tokoh-tokoh yang melawan konstruksi gender dengan hadir di ranah publik 3) Terdapat peranperan yang dilakukan tokoh-tokoh perempuan dalam usahanya mengatasi kemiskinan yang mereka alami. peran-peran tersebut antara lain membuka akses penjualan tembakau, menjalankan peran publik sebagai petani tembakau, memberikan pendidikan untuk anak-anak di Lereng Gunung Sindoro, menciptakan alternatif lapangan pekerjaan bagi perempuan, dan melibatkan perempuan dalam mengambil keputusan.
\end{abstract}

\begin{abstract}
This study is based on the female condition which tend to gain poverty. Many literatures used as a social critique towards prolems in real life, such as Genduk novel by Sundari Mardjuki. The aims of this research are :(1) to describe the poverty gained by female characters; (2) to describe gender construction; (3) to describe the roles of female characters in dealing with poverty in Genduk novel by Sundari Mardjuki.

The source of the data is taken from Genduk novel by Sundari Mardjuki published by Gramedia Pustaka Utama in 2016. The method used by the writer is descriptive-qualitative with literature feminism critique approach. This research is focus on the poverty occurred in female characters and their roles in dealing with it. The data are obtained by reading and taking notes technique.

The results of the analysis are as follows. 1) The image pattern of poverty occurred in female characters in Genduk novel by Sundari Mardjuki including: relative poverty covers the needs of clothes, houses, and foods, and also social image which covers the dependence on others and inability to adapt with environments. Seasonal poverty caused by economical sources. 2) The poverty occurred in women is related to gender
\end{abstract}


Bagus Afiansah dkk. / Jurnal Sastra Indonesia 7 (2) (2018)

construction prevail in each gender. However, Genduk, Yung and Bu As are the characters against the gender construction by existing in public 3) Roles of female characters in dealing with poverty which happen to them and their environment. The roles is opening an access to tobacco distributors, carrying out public role for women, giving education for childrens at Sindoro Valley, creating alternative job vacancy for woman, women involvement in getting decision.

(C) 2018 Universitas Negeri Semarang

$\bowtie$ Alamat korespondensi:
Gedung B1 Lantai 1 FBS Unnes

ISSN 2252-6315

Kampus Sekaran, Gunungpati, Semarang, 50229

E-mail: bagusiang@gmail.com 


\section{PENDAHULUAN}

Kemiskinan merupakan masalah kompleks yang dipengaruhi oleh berbagai faktor seperti pendapatan, pendidikan, gender, lokasi, dan kondisi lingkungan. Dari faktor gender, perempuan lebih rentan mengalami kemiskinan karena konstruksi sosial yang melekat pada mereka. Arjani (2007) mengungkapkan perempuan yang dalam banyak kebudayaan ditempatkan pada posisi sobordinat sering mengalami keadaan miskin, termarginalkan dan terdiskriminasi. Akar dari permasalahan yang dialami kaum perempuan tersebut adalah konstruksi gender yang berlaku di masyarakat. Maka dari itu, diperluakan solusi untuk mengatasi kemiskinan yang rentan dialami kaum perempuan. Salah satu solusi untuk menyadarkan masyarakat tentang kemiskinan yang rentan dialami perempuan adalah melalui karya sastra. Karya sastra dianggap menjadi dokumen sosial pada suatu masa. Sangidu (dalam Endaswara, 2013: 115) mengatakan bahwa sastra adalah bagian dari masyarakat. Maka tidak heran jika banyak permasalahanpermasalahan kehidupan nyata akan tergambar dalam karya sastra. Beberapa permasalahan seperti persoalan perempuan, kemiskinan, penindasan, hingga permasalahan gender dengan segala kompleksitasnya banyak dimunculkan para pengarang. Banyak kondisi yang digambarkan pengarang melalui cerita sebagai bentuk kepeduliannya terhadap kondisi sosial. Kondisi-kondisi seperti kemiskinan yang dialami kaum perempuan merupakan permasalahan yang penting untuk dibahas dan diteliti. Dalam penelitian sastra, digunakan teori feminisme hingga kritik sestra feminis sebagai bentuk kesadaran khusus bahwa perempuan merupakan makhluk yang mengalami ketidakadilan dari berbagai aspek. Sugihastuti dan Suharto (2013: 18) mengungkapkan dalam ilmu sastra, feminisme berhubungan dengan konsep kritik satra feminis, yaitu studi sastra yang mengarahkan fokus analisisnya pada perempuan. Dalam kaitannya dengan sastra, bidang studi yang relevan untuk diteliti diantaranya: tradisi literer perempuan, pegarang perempuan, pembaca perempuan, ciri-ciri khas bahasa perempuan, tokoh-tokoh perempuan, novel popular dan perempuan, dan sebagainya. Salah satu pembahasan yang penting untuk dibahas dalam karya sastra adalah kemiskinan yang dialami perempuan.

Novel Genduk karya Sundari Mardjuki merupakan salah satu novel yang didalamnya terdapat kondisi kemiskinan yang dialami perempuan. Dalam novel Genduk, pengarang memunculkan gambaran kemiskinan yang dialami tokoh-tokoh perempuan pada lingkup masyarakat petani tembakau. Selain itu, pengarang juga mengambarkan perjuanganperjuangan para tokoh perempuan yang mengambil peran-peran penting dan melakukan banyak pengorbanan untuk mengatasi kemiskinan yang mereka alami.

Dalam penelitian ini, rumuskan masalah yang dibahas mengenai: 1) gambaran kemiskinan yang dialami tokoh perempuan; 2) konstruksi gender yang berlaku pada masingmasing jenis kelamin; 3) peran tokoh-tokoh perempuan dalam mengatasi kemiskinan. Tujuan dalam penelitian ini adalah untuk memperoleh jawaban dari rumusan masalah yang telah dipaparkan sebelumnya. Dari rumusan masalah itulah peneliti ingin menunjukkan melalui karya sastra yaitu novel Genduk dapat memberikan penyadaran terhadap masyarakat tentang gambaran kemiskinan yang ternyata rentan dialami kaum perempuan. Penelitian ini juga diharapkan mampu memotivasi para perempuan untuk terus melawan konstruksi gender yang membelenggu mereka dan senantiasa mengambangkan diri agar terhindar dari bayang-bayang kemiskinan.

Adapun manfaat dari penelitian ini adalah dapat memberikan sumbangan pemikiran dan keilmuan bagi khazanah penelitian sastra di Indonesia, khususnya dalam kajian prosa berupa novel; memberikan wawasan dan proses pembelajaran bagi peneliti dalam mengkaji karya sastra menggunakan pendekatan kritik sastra feminis; hasil penelitian ini dapat menjadi acuan bagi peneliti lain yang akan meneliti novel Genduk karya Sundari Mardjuki ataupun novel lain dengan tema 
sejenis; bagi masyarakat secara umum, penelitian ini dapat memberikan pengetahuan tentang pola kemiskinan yang sering dialami masyarakat Indonesia; penelitian ini juga menjadi kritik sosial bagi pemerintah dan lembaga terkait untuk terus meningkatkan kebijakan-kebijakan yang adil gender serta terus melakukan upanya mengatasi kemiskinan yang ada di masyarakat.

Kemiskinan yang dialami kaum perempuan muncul sebagai akibat dari konstruksi gender. Noerdin (2006) mengungkapkan bahwa dalam masyarakat, banyak sekali stereotipe yang dilekatkan pada perempuan yang berakibat membatasi, menyulitkan, hingga memiskinkan kaum perempuan. Konstruksi gender telah membuat perempuan terbiasa dengan aktifitas di lingkup domestik yang membatasi perempuan untuk berkembang. Perempuan tidak diberi kesempatan untuk hadir di ruang publik dan mempelajari kahlian-keahlian yang dibutuhkan masyarakat. Hal tersebut juga yang mendorong perempuan semakin dekat dengan kemiskinan. Nur (2013) mengungkapkan bahwa Kemiskinan banyak dialami oleh masyarakat yang mempunya keterbatasan keahlian, sehingga dia tidak dapat bekerja dengan layak untuk memenuhi kebutuhan. Konstruksi gender mengakibatkan munculnya ketidakadilan, ketidaksetaraan, serta kesulitan ekonomi yang turut melahirkan kedekatan identitas perempuan dengan kemiskinan. Pandangan tersebut didukung dengan pernyataan Santi (2007) bahwa batasan-batasan yang dialami perempuan membuat perempuan rentan mengalami kemiskinan sehingga lingkaran kemiskinan banyak dimasuki perempuan lantaran kesenjangan dan ketidakberdayaan mereka.

Analisis yang pertama dilakukan dalam penelitian ini adalah mencari gambaran kemiskinan yang dialami tokoh-tokoh perempuan menggunakan teori kemiskinan. Chamber (dalam Khomsan et al, 2015) membagi bentuk kemiskinan menjadi empat: 1) kemiskinan absolut; 2) kemiskinan relatif; 3) kemiskinan kultural; 4) kemiskinan struktural. Sedangkan Sumodiningrat (1999) membagi kemiskinan menjadi empat pola seperti kemiskinan kronis, kemiskinan siklus, kemiskinan musiman, dan kemiskinan insiden. Selanjutnya peneliti melakukan kajian tentang konstruksi gender pada masing-masing jenis kelamin dengan memaparkan konstruksi gender baik tokoh laki-laki maupun tokoh perempuan. Kemudian pada bagian akhir peneliti menganalisis tentang peran-peran yang dilakukan para tokoh perempuan dalam mengatasi kemiskinan. Abdullah (2003) Gejala keterlibatan perempuan di luar rumah dan mengambil peran-peran penting di masyarakat menandakan bahwa perempuan telah merekonstruksi sejarah hidupnya, dengan membangun identitas baru bagi dirinya yang selama ini diidentikkan dengan peran-peran domestik. Keterlibatan perempuan memasuki sektor publik telah menjadi kekuatan penting di dalam menstransformasikan kehidupan perempuan secara umum.

Penelitian ini pada dasarnya mengkaji hubungan karya sastra dan keadaan yang dialami perempuan. Dalam keberagaman analisis karya sastra menggunakan disiplin feminisme, kritik sastra feminis digunakan peneliti karena relevan dengan permasalahan yang di kaji. Djajanegara (2003: 27) mengatakan pada umumnya, kritik sastra feminis dalam penerapannya dapat digunakan untuk mengkaji dari segi feministik karya sastra yang menampilkan tokoh perempuan. Baik cerita rekaan, lakon, maupun sajak bisa diteliti dengan pendekatan feministik, asal saja ada tokoh perempuannya. Penelitian tersebut akan lebih mudah jika tokoh wanita dikaitkan dengan tokoh laki-laki. Tidaklah menjadi soal apakah perempuan tersebut berperan sebagai tokoh utama, tokoh protagonis, atau tokoh sampingan. Teori lain yang digunakan dalam penelitian ini adalah konstruksi gender yang digunakan untuk melihat akar permasalahan yang dialami perempuan. Santi (2007) konsep gender adalah suatu konstruksi sosial atas peran perempuan dan laki-laki dalam masyarakat. Konstruksi ini telah melalui suatu proses sosial dan budaya yang sangat panjang dan lama sehingga mengakar dan dijadikan standar norma dalam 
masyarakat, bahkan menjadi ideologi gender. Manifestasi dari ideologi gender adalah relasi antara laki-laki dan perempuan yang sangat timpang dan tidak adil, antara lain berupa marginalisasi (kemiskinan ekonomi) kaum perempuan, subordinasi perempuan, pelabelan negatif (stereotype) pada perempuan yang menyebabkan terjadinya diskriminasi, kekerasan (violence) pada perempuan, dan beban kerja domestik yang lebih banyak dan lebih lama (multiple burden). Selain itu, digunakan juga ilmu sosial tentang kemiskinan untuk membantu mengupas permasalahan kemiskianan yang dialami perempuan dari sudut pandang kritik sastra feminis. Teori kritik sastra feminis digunakan karena sesuai dengan objek penelitian yang diambil yaitu mengenai tokoh perempuan.

\section{METODE PENELITIAN}

Metode yang digunakan dalam penelitian ini adalah deskriptif kualitatif dengan cara melukiskan data dan analisis dalam kritik sastra. Sedangkan pendekatan dalam penelitian ini adalah kritik sastra feminis. Data dalam penelitian ini yakni teks dalam novel Genduk karya Sundari Mardjuki yang mengandung unsur watak tokoh, pemikiran tokoh, tindakan tokoh, dan percakapan antar tokoh serta ulasanulasan mengenai novel Genduk baik berupa buku, artikel, maupun internet. Adapun teknik pengumpulan data yang digunakan dalam penelitian ini adalah baca-catat.

\section{HASIL PENELITIAN DAN PEMBAHASAN}

\section{Gambaran Kemiskinan yang Dialami Tokoh Perempuan}

Dalam penelitian ini, dilakukan analisis terhadap fenomena kemiskinan yang dialami tokoh-tokoh perempuan seperti Genduk dan Yung melalui percakapan antar tokoh, latar, maupun cerita dari sudut pandang tokoh utama. peneliti mencari data yang menunjukkan gambaran kemiskinan dengan membaca dan mencatat data yang menggambarkan kemiskinan. Setelah membaca dan mencatat kutipan novel yang berhubungan dengan kemiskinan, peneliti mengdeskripsikan kutipankutipan tersebut. Banyak data yang menggambarkan kemiskinan yang dialami tokoh-tokoh perempuan berupa tidak terpenuhinya kebutuhan hidup dengan layak. Penyebab kemiskinan yang dialami Genduk dan Yung adalah panen yang gagal serta tidak adanya sumber penghasilan.

Dari hasil analisis yang dilakukan peneliti, terdapat bentuk kemiskinan relatif dari data yang diperoleh. Kemiskinan relatif merupakan keadaan dimana seseorang masih bisa memenuhi kebutuhan dasar tetapi masih tertinggal dibandingkan lingkungan sekitarnya. Kemiskinan relatif tersebut dialami oleh Genduk dan Yung. Sementara itu, tidak adanya sumber penghasilan dan hanya mengandalkan profesi sebagai petani tembakau mengakibatkan Yung dan Genduk mengalami kemiskinan musiman tersebut.

Hal yang paling menonjol dari kemiskinan adalah tidak terpenuhinya kebutuhan dasar atau dapat memenuhi kebutuhan primer tapi masih di bawah kemampuan masyarakat pada umumnya. Kebutuhan pangan menjadi hal utama yang tidak terpenuhi dengan layak dan penyebabnya adalah tidak adanya penghasilan untuk memenuhi kebutuhan tersebut. Pengarang menggambarkan keadaan tokoh Genduk dan Yung yang hidup serba kekurangan di lingkup kehidupan petani tembakau di Lereng Gunung Sindoro. Selain pangan, kebutuhan lain yang tidak terpenuhi dengan layak adalah kebutuhan sandang dan papan. Untuk kebutuhan pangan, Genduk dan Yung memenuhi kebutuhannya dengan sumber makanan berupa singkong dan nasi jagung kerena ketidakmampuan membeli beras. Keadaan rumah tempat tinggal Genduk dan Yung juga kurang layak dilihat dari kondisi atap yang berlubang, tembok yang terbuat dari kayu, dan lantai tanah. Dalam memenuhi kebutuhan sandang, Yung tidak mampu membelikan rok baru untuk Genduk. Kondisi rok yang dimiliki Genduk warnanya sudah pudar dan sakunya berlubang. Pakaian yang dikenakan Genduk juga memprihatinkan karena 
setiap habis dicuci kemudian dipakai lagi oleh Genduk.

Penyebab kemiskinan yang dialami oleh Genduk dan Yung adalah tidak adanya sumber penghasilan karena penen tembakau yang gagal di musim sebelumnya. Selain itu, Genduk dan Yung hanya mengandalkan satu sumber penghasilan yaitu dari tanaman tembakau yang mengakibatkan pola kemiskinan musiman. Yung mengalami gagal panen yang mengakibatkan ia tidak memiliki penghasilan sama sekali untuk memenuhi kebutuhan hidup. Selain gagal panen, konstruksi gender juga turut menambah penyebab kemiskinan yang dialami Yung dan Genduk. Akibat dari tidak adanya sumber penghasilan, Genduk dan Yung harus mengandalkan bantuan pihak lain yaitu meminjam uang pada rentenir untuk kebutuhan hidup dan modal menanam tembakau. Untuk urusan menggarap lahan tembakau, Yung juga masih mendapat bantuan dari Lik Ngadun. Gambaran kemiskinan yang dialami Genduk dan Yung merupakan bentuk ketidakberdayaan dan ketidakadilan perempuan. Ditambah lagi, perempuan harus hidup dalam konstruksi gender yang merupakan produk dari masyarakat dan menjadi sumber permasalahan yang mereka alami. Selain itu, konstruksi gender juga sebagai salah satu penyebab kemiskinan yang mereka alami. Genduk dan Yung hanya mengandalkan sepetak ladang tembakau sebagai sandaran hidup dengan harapan mampu menghasilkan panen yang melimpah.

\section{Konstruski Gender dalam Novel Genduk}

Dari hasil analisis yang dilakukan peneliti, ditemukan bentuk konstruksi gender yang dilekatkan pada masing-masing jenis kelamin. Hal tersebut telah menimbulkan pembagian kerja dan dikotomi domestik-publik. Selain itu, konstrusi gender membagi dikotomi sifat maskulin yang lebih pantas dimiliki lakilaki dan feminim dilekatkan pada kaum perempuan. Tokoh-tokoh laki-laki yang digambarkan pengarang memiliki sifat-sifat maskulin adalah Lik Ngadun, Kaji Bawon, Sapto, Bah Djan, dan Kaduk. Tokoh-tokoh tersebut menjalankan peran dan memiliki sifat berdasarkan konstruksi gender yang berlaku di masyarakat. Konstruksi gender yang terdapat tokoh-tokoh laki-laki antara lain kuat, gempal, perkasa, sifat pemimpin, dan rasional. Begitupun dengan tokoh-tokoh perempuan, peneliti menemukan tokoh-tokoh seperti Sumiati, Genduk, dan Bu As memiliki sifat-sifat feminim tetapi dengan kadar yang berbeda. Genduk dan $\mathrm{Bu}$ As meskipun kental dengan atribut feminim, tetapi mereka juga menjalankan peran publik sebagai bentuk perlawanan konstruksi gender yang menempatkan perempuan di ranah domestik. sementara tokoh perempuan yang menjauhi atribut feminim adalah Yung. Hal itu dibuktiakan dari gambaran fisik maupun sifat yang dimiliki Yung. Konstruksi gender yang berlaku di masyarakat cenderung merugikan kaum perempuan. Hal tersebut dialami oleh Genduk yang mengalami pelecehan seksual oleh Kaduk. Genduk yang tidak memiliki kekuasaan dan lemah tidak melakukan perlawanan secara fisik dihadapan Kaduk. Genduk mendapatkan ancaman dari Kaduk bahwa dia tidak akan membawa tembakau Yung ke kota untuk dijual jika Genduk tidak menurutinya.

Sementara itu, peneliti menemukan salah satu tokoh perempuan yang secara tidak langsung melawan konstruksi gender yang derlaku di masyarakat. Peneliti menemukan tokoh perempuan seperti Yung telah merekonstuksi anggapan masyarakat tentang perempuan itu sendiri. Tokoh Yung membuktikan bahwa gender bisa dipertukarkan, entah dari fisik ataupun peran-peran dalam kehidupan. Yung merupakan satu-satunya tokoh perempuan yang digambarkan memiliki sifatsifat yang biasanya selalu dilekatkan pada lakilaki. Tidak seperti tokoh perempuan lain, Yung menjadi tokoh perempuan yang dikostruksikan memiliki watak pekerja keras dan fisiknya juga digambarkan seperti ciri-ciri pada laki-laki. Pekerjaan Yung sebagai petani tembakau turut mempengaruhi watak dan bentuk fisiknya. Apa yang dialami Yung sebagai bukti perempuan bisa kuat seperti laki-laki, begitupun sebaliknya laki-laki bisa lemah lembut seperti perempuan. Pada dasarnya bahwa konstruksi gender 
dibentuk, bukan merupakan takdir tuhan seperti jenis kelamin. Yung telah menjalankan peran sebagai petani tembakau seperti kebanyakan laki-laki di desanya. Hal itu menunjukkan bahwa laki-laki dan perempuan mempunyai potensi yang sama di berbagai sektor kehidupan.

\section{Peran Tokoh-tokoh Perempuan Mengatasi Kemiskianan}

Dalam mengatasi kemiskinan, para tokoh perempuan mengambil peran yang berbedabeda. Namun peran-peran tersebut saling berhubungan dalam upanya mengatasi kemiskinan pada diri mereka dan lingkungannya. Pengarang menampilkan kehidupan tokoh perempuan seperti Genduk dan Yung yang miskin hidup di lingkungan petani tembakau yang juga rentan terhadap kemiskinan. Genduk dan Yung berusaha keras keluar dari fenomena kemiskinan yang mereka alami dengan banyak pengorbanan. Bahkan Genduk rela mengorbankan harga dirinya di hadapan Kaduk karena keadaan miskin yang ia alami. Tapi pengorbanan yang dilakukan Genduk sia-sia karena pada akhirnya Kaduk menipu Geduk dan ibunya. Hingga pada akhirnya Genduk yang nekat turun ke Kota parakan saat dalam upaya mencari keberadaan bapaknya mempu membuka akses dengan juragan tembakau yang bersedia membeli tembakau dari para petani di desanya.

Dari hasil analisis yang dilakukan peneliti, peran-peran yang dilakukan para tokoh perempuan dalam mengatasi kemiskinan adalah membuka akses penjualan tembakau, menjalankan peran sebagai petani tembakau, menciptakan alternatif lapangan pekerjaan bagi perempuan, memberikan pendidikan bagi anakanak di Lereng Gunung Sindoro, dan melibatkan perempuan dalam mengambil keputusan. Peran membuka akses penjualan tembakau dilakukan oleh Genduk. Peran ini sangat penting dan diperlukan untuk mengatasi kemiskinan yang dialami para petani tembakau. Selain itu, adanya akses langsung penjualan tembakau juga untuk melawan keberadaan tengkulak dan gaok. Tembakau-tembakau milik petani dapat dijual langsung tanpa perantara tengkulak dan gaok yang sering mengakali petani dan mempermainkan harga tembakau. Kemudian keterlibatan perempuan di ruang publik dilakukan oleh Yung dengan menjadi petani tembakau. hal itu dilakukan Yung sebagai usaha mendapatkan penghasilan dan keluar dari jurang kemiskinan. kegigihan Yung dalam mengolah ladang tembakaunya pada akhirnya memberikan hasil yang sepadan. Ladang yang dikelola Yung berhasil menghasilkan tembakau srintil yang dikenal dengan tembakau terbaik dan harga jualnya paling tinggi. Selanjutnya menciptakan alternatif pekerjaan juga diperankan Yung berkat usaha yang dilakukan oleh Genduk. Yung dipercaya menjadi penghubung petani dengan Bah Djan. Penjualan tembakau pera petani melui Yung. Perekerjaan Yung yang baru ini sekaligus menyingkirkan keberadaan gaok dan tengkulak yang meresahkan para petani.

Bukan hanya Genduk dan Yung, tokoh $\mathrm{Bu}$ As juga memerankan peran penting dalam mengatasi kemiskinan dengan memberikan pendidikan untuk anak-anak di Lereng Gunung Sindoro. Peneliti menemukan gambaran perjuangan $\mathrm{Bu}$ As harus pergi ke desa-desa di Lereng Gunung Sindoro. Bu As menyadari bahwa pendidikan menjadi sarana penting dalam upaya membangun bangsa. Meskipun hidup di lereng gunung, anak-anak Sindoro harus tetap mendapatkan pendidikan demi masa depan mereka. Pendidikan merupakan salah satu langkah mengatasi kemiskinan. Salah satu faktor ketidakmampuan orang untuk berkembang karena tidak memiliki ilmu pengetahuan dan keterampilan. Hal itu menyebabkan seseorang semakin rentan mengalami kemiskinan. Dalam novelnya, pengarang memunculkan ironi bahwa warga desa lebih mementingkan tembakau-tembakau mereka dibanding pendidikan anaknya. Hal itu terjadi saat musim panen tembakau tiba dan anak-anak lebih memilih membantu orangtuanya di ladang dariapada pergi ke sekolah.

Dalam pembahasan ini, peran mengatasi kemiskinan terakhir adalah melibatkan perempuan dalam mengambil kebijakan. Hal itu 
diperankan oleh Genduk dan Yung saat pak lurah melakukan rapat di balai desa bersama seluruh perangkat dan sesepuh desa. Rapat tersebut untuk menentukan langkah petani menghadapi tengkulak dan langkah-langkah yang harus dilakukan para petani setelah akses menjual tembakau langsung ke juragan tembakau telah terbuka. Keterlibatan Genduk dan Yung sebagai bentuk dari peran mereka mendorong kesejahteraan para petani tembakau di desa tempat mereka tinggal. Perempuan harus dilibatkan dalam setiap pengambilan kebijakan, terutama kebijakan yang berhubungan dengan publik. Kehadiran perempuan dalam mengambil keputusan adalah wujud kadilan gender serta agar setiap keputusan yang diambil bisa netral gender.

\section{SIMPULAN}

Berdasarkan hasil analisis di atas, dapat disimpulkan bahwa novel Genduk karya Sundari Mardjuki menggambarkan kemiskinan yang dialami perempuan. Akan tetapi tokoh-tokoh perempuan tersebut terus berjuang mengatasi kemiskinan yang mereka alami. Gambaran kemiskinan yang ada dalam novel Genduk berupa ketidakmampuan memenuhi kebutuhan dasar dengan layak. kemiskinan yang dialami tokoh perempuan yaitu Genduk dan Yung karena tidak ada sumber penghasilan. Dampak dari kemiskinan yang dialami Genduk dan Yung adalah ketergantungan terhadap pihak lain dan rasa rendah diri. Terdapat kostruksi gender yang melekat pada masing-masing tokoh. semua tokoh laki-laki memiliki konstruksi gender berupa sifat-sifat maskulin. Sementara tokohtokoh perempuan seperti Sumiati, Bu As, dan Genduk memiliki sifat feminim pada diri mereka. Yung merupakan tokoh perempuan yang melawan konstruksi gender pada diri perempuan. Dalam novel ini, meskipun perempuan mengalami kemiskinan, tetapi mereka tidak pernah pasrah dengan keadaanya dan terus berjuang keras agar kemiskinan yang dekat dengan mereka dapat diatasi. Dalam menggambarkan kemiskinan perempuan, pengarang memunculkan kehidupan di sebuah desa di Lereng Gunung Sindoro yang hampir seluruh penduduknya berprofesi sebagai petani tembakau. Para tokoh perempuan seperti Genduk, Yung, dan $\mathrm{Bu}$ As bukan saja dihadapkan pada konstruksi gender, tapi juga keadaan geografis serta ancaman dari para tengkulak dan gaok. Peran-peran diambil para tokoh perempuan untuk mengatasi kemiskinan antara lain: 1) membuka akses penjualan tembakau; 2) menjalankan peran sebagai petani tembakau; 3) memberikan pendidikan bagi anak-anak di Lereng Gunung Sindoro; 4) menciptakan alternatif lapangan pekerjaan bagi perempuan; 5) melibatkan perempuan dalam mengambil keputusan.

\section{DAFTAR PUSTAKA}

Abdullah, Irwan. 2003. Sangkan peran Gender. Yogyakarta: Pustaka Pelajar.

Arjani, Ni Luh. 2007. "Feminisasi Kemiskinan dalam Kultur Patriarki". Universitas Udayana. Jurnal Studi Jender Srikandi Vol.6 No:1. http://ojs.unud.ac.id/index.php/srikandi/arti cle/view/2878 diakses 22 Januari 2017.

Djajanegara, Soenarjati. 2003. Kritik Sastra Feminis: Sebuah Pengantar. Jakarta: Gramedia Pustaka Utama.

Endraswara, Suwardi. 2013. Teori Kritik Sastra: Prinsip, Falsafah, dan Penerapan Yogyakarta: CAPS (Center for Academic Publishing Service).

Mardjuki, Sundari. 2016. Genduk. Jakarta: Gramedia Pustaka Utama.

Khomsan, Ali. Dkk. 2015. Indikator Kemiskinan dan Misklasifikasi Orang Miskin. Jakarta: Yayasan Pustaka Obor Indonesia.

Noerdin, Edriana. Et al. 2006. Potret Kemiskinan Perempuan: Strategi Pengentasan Kemiskinan Berbasis Gender. Jakarta: Women Research Institite.

Nur, Andri Kharisma. 2013. "Gambaran Kemiskinan dalam Novel Padang Bulan Karya Andrea Hirata (Tinjauan Sosiologi Sastra)". Skripsi S1 Universitas Negeri Yogyakarta. Yogyakarta

Santi, Sarah. (2007). "Perempuan dan Kemiskinan: Pembangunan, Kebijakan, dan Feminisasi Kemiskinan". Forum Ilmiah Indonusa. Vol 4 No:1.

http://sinta1.ristekdikti.go.id/index.php?ref $=$ j ournal\&mod=viewjournal\&journal=5028\&iss 
ue $=\% 20 \mathrm{Vol} \% 204, \% 20 \mathrm{No} \% 2001 \% 20(2007): \%$

20Forum\%201lmiah diakses 1 April 2017.

Sugihastuti dan Suharto. 2002. Kritik Sastra Feminis: Teori dan Aplikasinya. Yogyakarta: Pustaka Pelajar.

Sumodiningrat, Gunawan. dkk. 1999. Kemiskinan: Teori, Fakta, dan Kebijakan. Jakarta: Penerbit Impac. 